\title{
Fluid Inclusion Study of Epithermal Gold-Base Metal Mineralization in the Shwebontha Prospect, Monywa Mining District, Central Myanmar
}

\author{
Toe Naing Oo*1,2, Agung Harijoko ${ }^{1}$, and Lucas Donny Setijadji ${ }^{1}$ \\ ${ }^{1}$ Department of Geological Engineering, Faculty of Engineering, Universitas Gadjah Mada, Yogyakarta, Indonesia \\ ${ }^{2}$ Department of Geology, Kyaing Tong University, Keng Tung, Myanmar
}

\begin{abstract}
The Shwebontha Prospect area is one of the prominent epithermal Au-Ag prospects in the Monywa mining district, central Myanmar, characterized by gold-bearing and base metal quartz veins. The gold grade is around 3 to $10.4 \mathrm{~g} / \mathrm{t}$. The area's lithology consists of the volcanic and volcaniclastic rocks of the Upper Oligocene-Middle Miocene Magyigon Formation that served as the ore's host rock mineralization. The host rocks are followed by silicification and propylitic and argillic alteration. The mineralization styles are gold-bearing brecciated quartz veins, and chalcedonic quartz veins sulfides are clustered as well as disseminated both in quartz gangue and volcanic host rocks. Those quartz veins include pyrite, sphalerite, galena, chalcopyrite, and gold. Fluid inclusion microthermometric indicates that the ore mineralization is characterized by the values of homogenization temperature range from 158 to $310^{\circ} \mathrm{C}$ and salinities range from 0.35 to $2.41 \mathrm{wt} . \%$ $\mathrm{NaCl}$ equivalent. Microthermometric data indicates that fluid mixing and dilution were significant processes during ore mineralization and hydrothermal fluids' evolution. Based on the petrography of fluid inclusion, microthermometric measurements, and ore minerals assemblage, estimation of paleo-depth and hydrothermal alteration types from the Shwebontha Prospect implies forming under an epithermal environment.
\end{abstract}

Keywords: Shwebontha - Wuntho Popa Magmatic Arc · Mixing and dilution · Epithermal - Gold-based metal mineralization · Fluid inclusion.

\section{INTRODUCTION}

The Monywa mining district is one of the important metallogenic belts in terms of the great potential of high sulfidation epithermal-type deposits and low sulfidation epithermal-type $\mathrm{Au}$ mineralization occurred in the area west of Chindwin River (the Monywa City), Central Myanmar (Figure 1, 2) (Mitchell et al., 2011; Knight and Zaw, 2015). There are four well-known high sulfidation copper-gold ore deposits such as Sebataung, Sebetaung South, Kyisintaung, and Letpadaung and other minor gold prospects Kyaukmyet, Shwebontha,

\footnotetext{
${ }^{*}$ Corresponding author: T.N. OO, Department of Geology, Kyaing Tong University, Room no (T-07) Tonkapuri Hostel, Keng Tung, Myanmar. E-mail: toenaingoo.geol84@gmail.com
}

Taungzone, Myeik in Monywa mining district as seen in Figure 2.

The Shwebontha Prospect is situated about $1 \mathrm{~km}$ ENE of the Letpadaung $\mathrm{Cu}-\mathrm{Au}$ deposit in which operating mining (Figure 2). Tectonically, this research area is a part of the wellknown Wuntho Popa Magmatic Arc (Figure 1), which is one of the distinct geological features and metallogenic provinces in Myanmar. In general, gold deposits within the Wuntho Popa Magmatic Arc can be recognized as subductionrelated granites and intimately associated with porphyry-type copper-gold and epithermal gold-base metals mineralization (Gardiner et al., 2015). The Ivanhoe Copper Company Limited previously explored the prospect area. The discovery of gold-base metals mineralization had been conducted through detailed explo- 


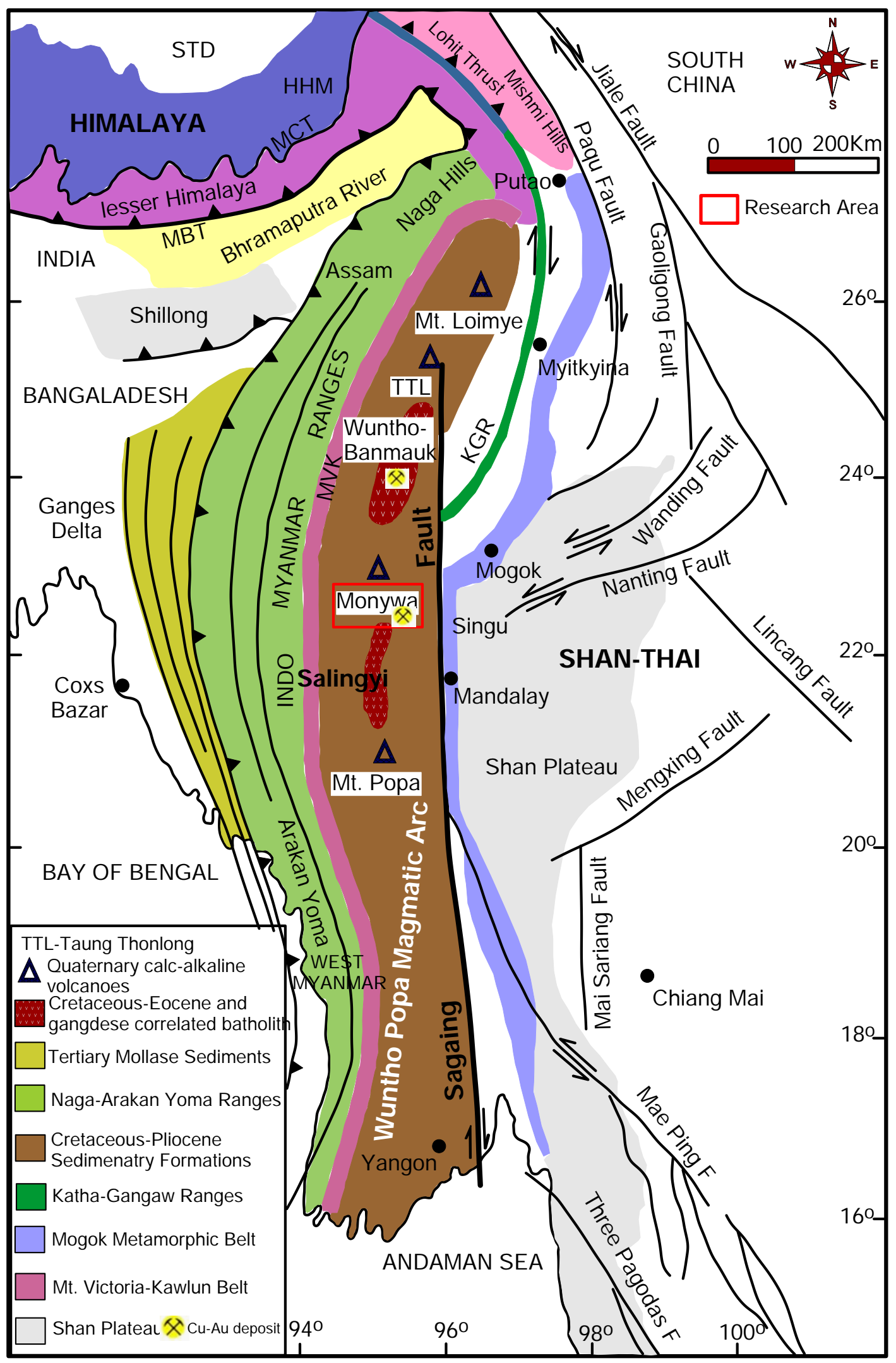

FIGURE 1. Simplified geological map showing structural features, Tertiary volcanoes, and Wuntho Popa Magmatic Arc in Myanmar and related regions (modified from Searle et al., 2007; Lee et al., 2016). 


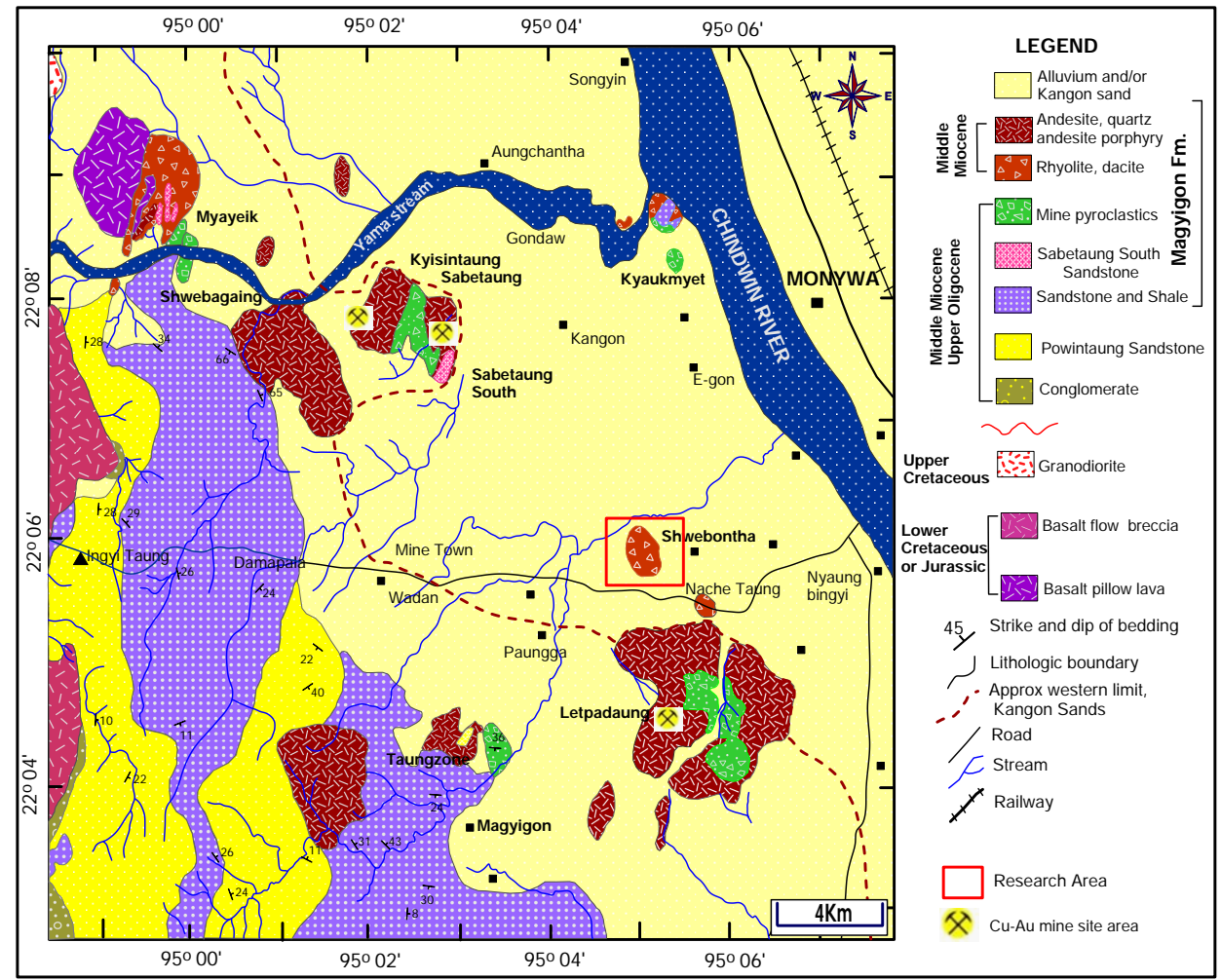

FIGURE 2. Regional geological map of Monywa copper-gold district (modified after Mitchell et al., 2011).

ration, including geological and geophysical investigation. Gold and base metals mineralization is mainly hosted in the rhyolite unit and sometimes observed in the hydrothermal breccia unit. A field study recorded that the principal two types of mineralization veins are identified, such as gold-bearing brecciated quartz vein and chalcedonic quartz vein. Both quartz veins are intimately associated with gold and base metals mineralization. They are trending in a nearly NE-ENE direction as a result of controlling regional structure. The Shwebontha Prospect area is characterized by extensive hydrothermal alteration. Altered rocks belong to volcanic and volcaniclastic rocks of the Upper Oligocene to Middle Miocene age, and rock types consist of rhyolite, tuff breccia, and hydrothermal breccia. The most common hydrothermal alterations in the research area include silicification and argillic and propylitic alteration types. Silicification consists of quartz and pyrite. Argillic alteration is characterized by quartz \pm kaolinite \pm illite \pm smectite, whereas propylitic alteration is dominated by quartz, chlorite \pm illite \pm smectite, pyrite assemblages (Oo et al., 2019).

Previous exploration data suggested that the maximum gold grade in the diamond drilling range from 3 to $10.4 \mathrm{~g} / \mathrm{t}$ (Leach et al., 1996) (unpublished data). And also, the concentration of base metals content of $\mathrm{Cu}(12.45 \mathrm{ppm})$, $\mathrm{Pb}$ (105.43 ppm), Zn (392.96 ppm), As (115.92 ppm), and Sb (5.299 ppm) in the drill core analysis (Htet, 2008) (unpublished data). However, no data was published regarding the mineral deposit type and ore mineralogy and the study of the fluid inclusion of the Shwebontha Prospect. This paper focuses on the detailed description of fluid inclusion study to understand hydrothermal fluids' characteristics during ore mineralization and the possible paleodepth and temperature of formation of goldbearing and base metal quartz veins in the Shwebontha Prospect.

\section{Geological Setting}

Myanmar is conveniently located in the eastern margin of the India-Asia collision zone characterized by the existence of the $1500 \mathrm{~km}$ long N-S trending well-known Sagaing Fault, which links the eastern Himalayan Syntaxis to the north and the Andaman Sea to the south (Searle et al., 2007; Mitchell et al., 2007; Lee et al., 2016) Figure 1. This renowned Sagaing fault 
medially divides Myanmar into the eastern part (Shan-Thai Block) and the western part (Western Burma Block). The eastern part consists of the Sibumasu terrane encompassing the Shan Plateau, the Mogok-Mandalay-Mergui Belt (MMMB), and the Shan Scarps. On the other hand, the western part belongs to the West Burma terrane comprising the Indo-Myanmar Ranges and the Wuntho Popa Magmatic Arc system, as seen in Figure 1 (Mitchell et al., 2012). The Wuntho Popa Magmatic Arc and the Mogok-Mandalay-Mergui Belt (MMMB) are $\mathrm{N}-\mathrm{S}$ trending magmatic and metallogenic belts in Myanmar. Based on the previous studies' geochronological data (Zaw, 1990; 2017), the Wuntho Popa Magmatic Arc system is characterized by the Late Cretaceous to Tertiary granodioritic intrusive rocks with a subordinate sequence of the volcanic rocks of Late Cretaceous to Quaternary ages.

The Monywa mining district is located in the Wuntho Popa Magmatic Arc, within the Central regional belt of Myanmar (Win and Kirwin, 1998; Mitchell et al., 2011; Zaw, 2017). This district attracts attention to geologists as a result of the tremendous economic potential of the $\mathrm{Cu}$-Au deposit. Metallic mineralizations are found in high sulfidation epithermal-type $\mathrm{Cu}$ deposits and low sulfidation epithermal-type $\mathrm{Au}$ mineralization in the Monywa mining district. Its resources before mining is about 2 billion tonnes of ore with more than 7 million tonnes comprised copper, forming Monywa is the second-largest epithermal-type $\mathrm{Cu}$ deposit in S.E. Mainland Asia (Mitchell et al., 2011; Zaw et al., 2017). The Monywa copper deposits and gold-silver prospects (including Shwebontha prospect) lie a few kilometers east of a cluster of small inliers of basement rocks and granitic intrusions that coincide with a regional aeromagnetic anomaly on the geanticline axis (Kirwin, 1994). The basement rocks are overlain locally by volcanic rocks. Both are overlain unconformably by eastward-dipping quartzofeldspathic sandstone of probable Eocene age, with a prominent west-facing scrap slope at Powintaung. The metallic deposits between Powintaung and the Chindwin River are primarily hosted by the Magyigon Formation and porphyry intrusions (Figure 2).

\section{Research Methods}

A field investigation was carried out during the winter season of 2018. A detailed field investigation was carried out by field mapping, data collection, and sampling. About twenty-five samples were collected from the Shwebontha Prospect, Monywa mining district. The collected samples were carefully chosen for ore microscopy and fluid inclusion study. Of these, five polished sections of ore samples were made for selected samples and examined under reflected-light optical microscope study to record the ore mineral assemblages and textural relationships. Alternatively, selected five quartz vein samples from 2 main veins, such as gold-bearing brecciated quartz vein and chalcedonic quartz vein, were conducted for fluid inclusion study. Those chosen gold-bearing brecciated quartz vein and chalcedonic quartz vein are associated with gold and base metals mineralization and clear quartz samples that easily observe and interpret for fluid inclusions study under the microscope. Firstly, doubly polished thin sections between 100 to $200 \mu \mathrm{m}$ thickness were prepared from mineralized quartz vein samples for preliminary petrographic observation. The distribution pattern, shapes, sizes, nature of occurrences, and phase content of fluid inclusions within quartz crystals were examined systematically to identify the fluid inclusion assemblages and the types of fluid inclusions, especially in primary and secondary inclusions based on the standard criteria of Roedder (1984) and Bodnar et al. (1985). Fifty-seven fluid inclusions were measured to obtain microthermometric data, especially homogenization temperature and final-ice melting temperature. Microthermometric measurements were made using a Linkam TH600 combined heating and freezing stage with a temperature range of -196 to $+600^{\circ} \mathrm{C}$ and attached to a Nikon petrographic microscope Axiovision software where temperature reproducibility is $\pm 0.1^{\circ} \mathrm{C}$. All laboratory analyses were done at the Department of Earth Resource Engineering, Kyushu University, Fukuoka, Japan.

\section{Geology of Research Area}

The Shwebontha Prospect is predominantly volcanic igneous rock, volcaniclastic, and sed- 
imentary rocks, including rhyolite, hydrothermal breccias, tuff breccias, tuff, tuffaceous sandstones as well as alluvium deposit (Figure 3). Stratigraphically, the hydrothermal breccia is the oldest rock unit in the research area, where it is distributed in the central part. The hydrothermal breccia unit is unconformably underlain by the rhyolite rock unit, which is the most dominant rock unit in the research area. Gold and base metals mineralization is mainly hosted by a rhyolite unit and hydrothermal breccias unit, an Upper Oligocene-Middle Miocene Magyigon Formation member. Most mineralization veins are observed in the silicic alteration zone, where gold is associated with pyrite, galena, sphalerite, and chalcopyrite (Oo et al., 2019). Their vein trends are generally followed by the regional structural trend, probably related to being NE-ENE trending in a direction responsible for forming gold and base metals mineralization in the study area.

\section{RESUlts AND Discussion}

\subsection{Results}

\section{Gold mineralization and paragenesis}

In the Shwebontha Prospect area, gold mineralization is mainly hosted by rhyolite rock unit and hydrothermal breccias. Massive brecciated gold-bearing quartz veins focused on the main veins and in zones of argillic altered wall-rocks and oxidized zones (Figure 4). The veins have regular sharp boundary contacts with rhyolite host rock unit and hydrothermal breccia, indicating that they are also likely to be formed by open-space filling and sometimes disseminated nature. Sulfide minerals also occur as in the chalcedonic quartz veins alternating with strongly silicified zones cut by cherty or sugary quartz vein in the rhyolite host rock and within the hydrothermal breccias and as dissemination (Figure 4). Mineralization is associated with alteration characterized by quartz, kaolinite, chlorite, illite/smectite mineral assemblage. Pyrite, galena, sphalerite, and chalcopyrite are the major primary sulfide minerals (Oo et al., 2019). Pyrite is the visible sulfide of the ore mineral in the rhyolite unit's host rock and hydrothermal breccia (Figure 4). The oxidized zone of iron oxides generally caps the mineralized zone. Iron oxides such as goethite and hematite occur as supergene oxidized ores. The textural relationship among ore and gangue minerals assemblage indicates that the ore-forming processes result from multiple episodic ore fluid movements and ore depositions. For the Shwebontha gold mineralization, the paragenesis of ore deposition can be described as follows: the early stage is characterized by wall rock alteration and early pyrite formation. The later ore stage is preceded by fracturing, brecciation, and subsequent deposition of gold and sulfides (pyrite, sphalerite, galena, and chalcopyrite). The latest stage is the oxidization of primary sulfides, which gave rise to the formation of covellite and iron oxides such as goethite and hematite.

Ore Microscopy The common ores in the mineralized veins of the Shwebontha area include pyrite, sphalerite, galena chalcopyrite, and gold (electrum) (Figure 5). Pyrite is the abundant sulfide mineral in the Shwebontha prospect. It is characterized by euhedral form, mostly in cubic form. The pyrite generally has a diameter of 0.1-1 mm. Euhedral pyrite crystals found almost the entire period of mineralization (Figure 5). Some of the euhedral to subhedral pyrite grains are found as cataclastic and intimately associated with chalcopyrite, galena, and sphalerite. Sphalerite is one of the common ore minerals in the Shwebontha deposit and is generally in contact with and replaced by galena in the pyrite matrix (Figure 5b, c). Sphalerites show grey color, irregular shapes, display internal reflection, pyrite, galena, and chalcopyrite (Figure $5 b, c)$. Some sphalerite found intergrowth with pyrite crystal in the gangue matrix (Figure 5d). Galena occurs as white to light grey color, anhedral, bulb, rounded, and elongated forms (Figure 5b, c). It is observed in the euhedral pyrite matrix and associated with pyrite, sphalerite, and chalcopyrite. Galena sometimes encloses earlier-formed sphalerite. Some sphalerites are locked within the grain boundary of galena. Chalcopyrite occurs as fine-mediumgrained sulfide minerals in the research area. It forms a late filling phase along the fracture or early-formed pyrite as an irregular patch in a minor amount (Figure 5e, f). It is associated with pyrite and gold. In the polish section, gold is mainly found as native gold or electrum granular grain in the euhedral pyrite crys- 


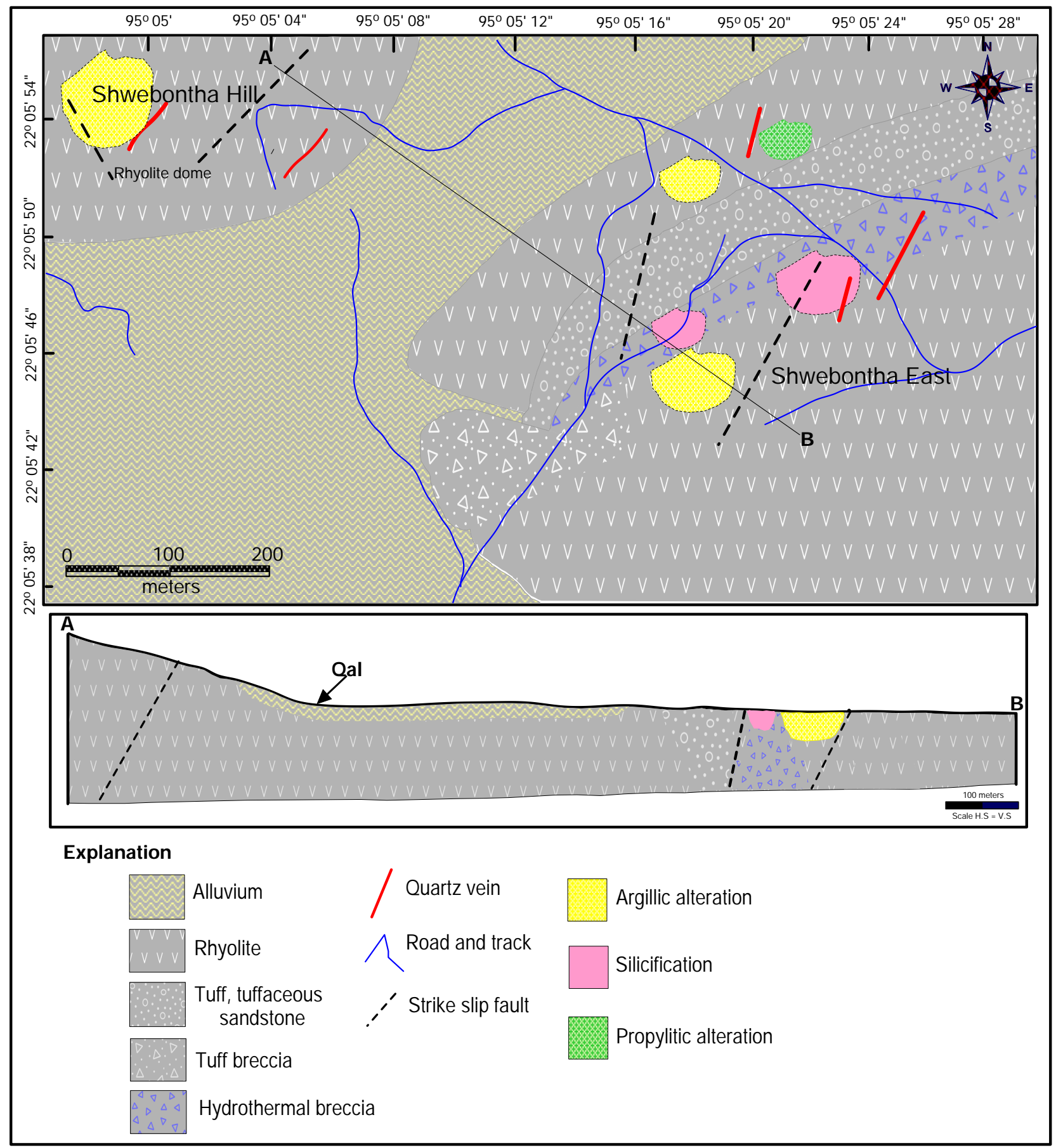

FIgURE 3. A Geological Map of the Shwebontha Prospect area, Monywa Mining District, Central Myanmar, and cross-section along A-B is also shown (modified from Htet, 2008). 
Fluid InClusion Study of Epithermal Gold-Base Metal Mineralization in the SHWebontha

PROSPECT
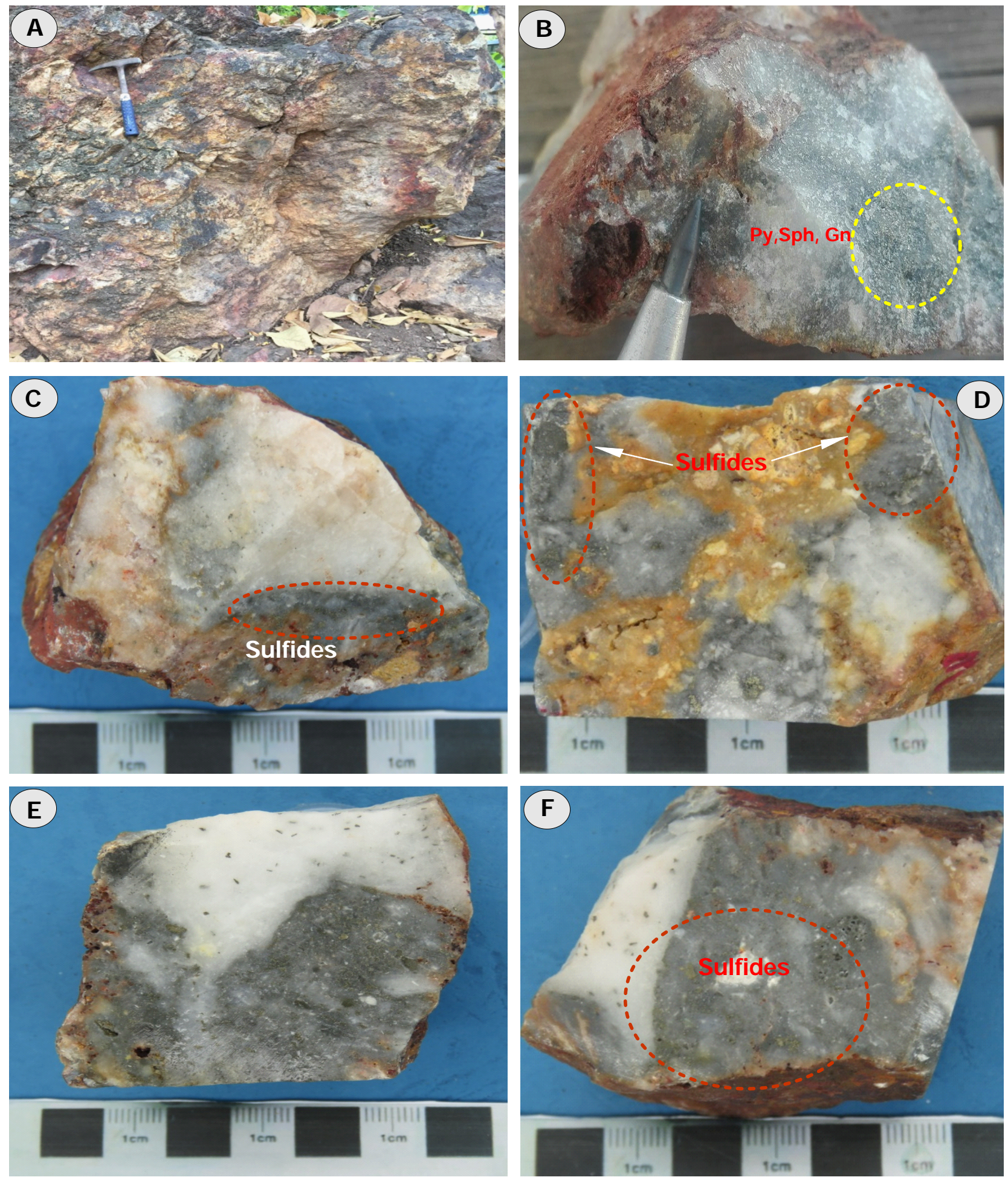

FIGURE 4. Photographs showing (a) massive ore bodies in the argillic altered rhyolite host rock occurring near the Shwebontha Monastery; (b, c) chalcedonic quartz vein in the rhyolite host rock; $(d, e, f)$ gold-bearing brecciated quartz veins. 
tal and associated with pyrite and chalcopyrite (Figure 5f). Other copper ore minerals of supergene $\mathrm{Cu}$-sulfides (covellite) replace hypogene $\mathrm{Cu}$-sulfides such as chalcopyrite (Figure $5 \mathrm{~g}$ ). Goethite's iron oxide mineral occurs as concentric banding nature in the gangue matrix (Figure $5 \mathrm{~h}$ ). It is usually associated with pyrite, where goethite is typically formed under the oxidizing condition as a weathering product of iron sulfide minerals such as pyrite.

\subsection{Discussion}

\section{Petrography of fluid inclusion}

Microthermometric analyses of fluid inclusions were carried out mainly on doubly polished thin sections chosen from different quartz veins containing inclusions from the Shwebontha deposit. All of the selected quartz samples are associated with gold and base metals mineralization. In these vein samples of fluid inclusions are also likely to be believed as primary fluid inclusions. The primary fluid inclusions mainly occur as two-phase (liquid + vapor) fluid inclusions, and liquid-rich two-phase inclusions are dominant. The phase relationships observed under the microscope at room temperature and during the experiments, distinguish as two principal types of fluid inclusions in the studied quartz: two-phase liquidrich (Type I) and two-phase vapor-rich (Type II), follow up the classification of Shepherd et al., 1985 and Rodder, 1984. Type I fluid inclusions generally consist of a vapor bubble and liquid phase. These are liquid-rich and contain $<50$ vol.\% (mostly 10-30 vol.\%) vapor phase, which occurs along the quartz's growth zones and isolated planes. However, the Type II fluid inclusions are characterized by a giant vapor bubble that generally belongs to $>75 \mathrm{vol} . \%$ of the volume of the fluid inclusion (optical examination), which occurs as isolated inclusions. In general, Type I fluid inclusions are dominant than Type II inclusions in all samples, whereas Type II inclusions are relatively limited and were only found in individual thin sections. Moreover, there is also a rare coexisting liquid-rich two-phase (Type I) and vapor-rich two-phase (Type II) inclusions in the Shwebontha deposit, suggesting that only restricted boiling fluid occurred during ore mineralization. The fluid inclusions are generally $5-10 \mathrm{~mm}$ in size and rarely up to $15 \mathrm{~mm}$ in size. The morphology of primary fluid inclusions was observed as elongated, sub-rounded, irregular, or negative crystal shapes within quartz crystals (Figure 6).

\section{Fluid inclusion microthermometry}

The common two-phase liquid-rich fluid inclusions from the different mineralized quartz veins were performed to conduct microthermometric measurement. This study has supported understanding the nature and characteristics of fluid inclusions such as temperature, pressure, density, and estimate paleo-depth of formation. A total of 57 fluid inclusions from 5 quartz vein samples from 2 samples of gold-bearing brecciated quartz veins and chalcedonic quartz veins were analyzed for homogenization temperature $(T h)$ and final ice melting temperature (Tm). Based on the fluid inclusion data, the homogenization temperature $(\mathrm{Th})\left({ }^{\circ} \mathrm{C}\right)$ for chalcedonic quartz vein ranges from 158 to $298^{\circ} \mathrm{C}$, and gold-bearing brecciated vein ranges from 165 to $310^{\circ} \mathrm{C}$, respectively (Figure 7). The final ice-melting temperature of fluid inclusion data ranges from -0.2 to $-1.4^{\circ} \mathrm{C}$ with an average of $-0.8^{\circ} \mathrm{C}$. By applying Bodnar's equation (1993), fluid inclusion's salinity is calculated from the melting temperature. The salinity value ranges from 0.35 to $2.41 \mathrm{wt}$.\% $\mathrm{NaCl}$ equivalent with an average salinity of $1.38 \mathrm{wt} . \% \mathrm{NaCl}$ equivalent (Figure 7). Frequency distributions of homogenization temperature and salinity diagram from different quartz veins show uni-modal distribution (Figure 7).

A compilation of homogenization temperature versus salinities was used to distinguish the mineral deposit type (Wilkinson, 2001). Shwebontha fluid inclusions characterized by low to medium homogenization temperature (Th) and low salinity values were plotted in the field for the epithermal deposit (Figure 8). Moreover, fluid densities are also necessary regarding the mechanism of fluid flow and evaluation of spatial variations in the fluid that constrain the flow process (Wilkinson, 2001). Based on the homogenization temperature versus salinity diagram, the Shwebontha Prospect area's fluid inclusion densities are calculated where the density range is between 0.7 and 0.9 $\mathrm{g} / \mathrm{cm}^{3}$ (Figure 9). In general, higher densities of 

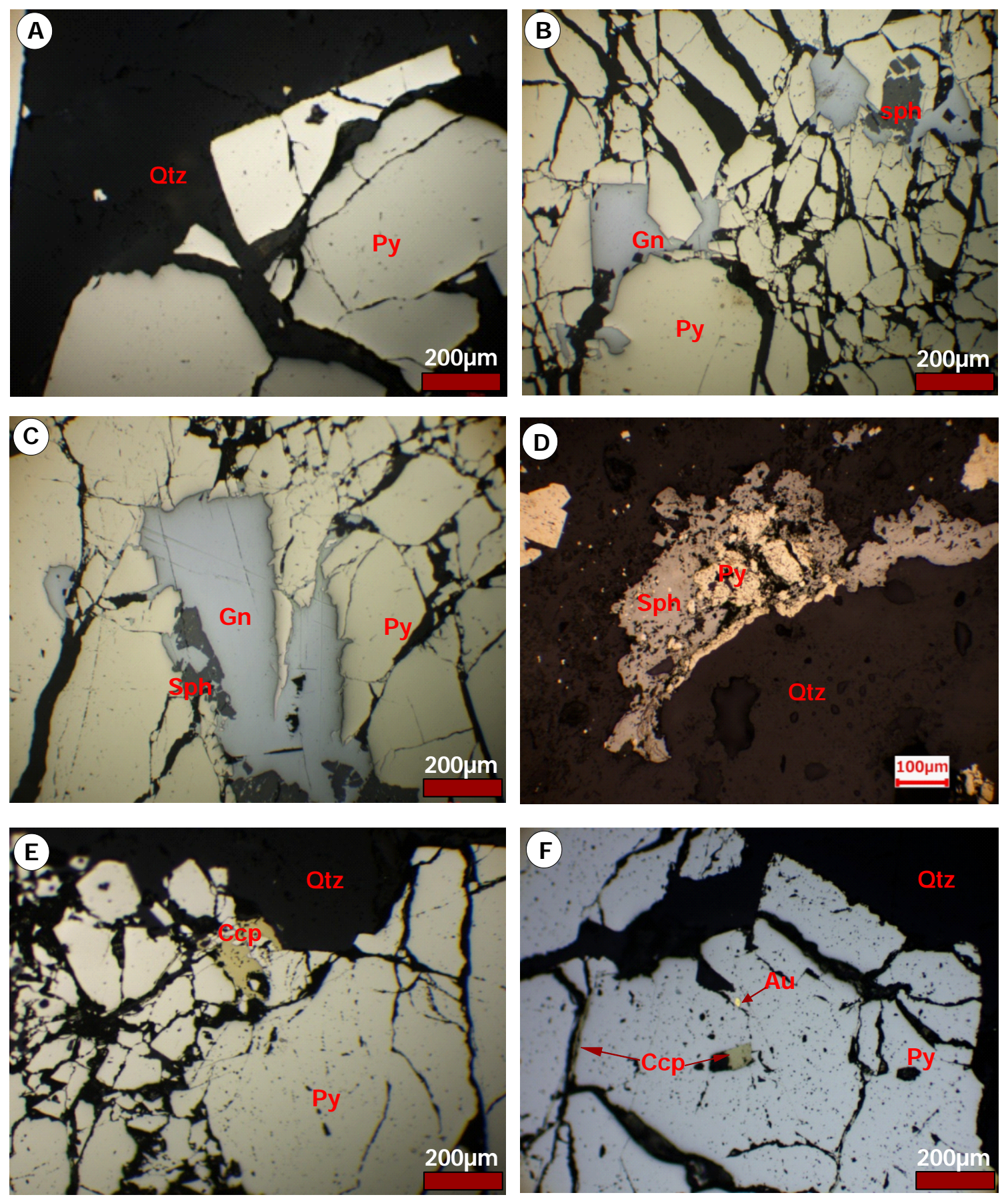

FIGURE 5. Reflected light photomicrographs of ore minerals in mineralized quartz veins from the Shwebontha Prospect (a) euhedral pyrite crystal in the gangue matrix; (b) euhedral pyrite crystal is replaced by galena and sphalerite; (c) white to the light gray color of elongated galena formed in euhedral pyrite matrix; (d) sphalerite and pyrite are intergrowth in the gangue matrix; (e, f) chalcopyrite occurred as inclusion and fissure filling in subhedral to euhedral pyrite crystal; (f) large crystal pyrite replaced by chalcopyrite, and fine-grained gold; $(g, h)$ covellite, goethite and pyrite observed as inclusion in gangue matrix. Abbreviations: Py: pyrite, Gn: galena, Sph: sphalerite, Ccp: chalcopyrite, Au: gold, Cv: covellite, Goe: goethite, Qtz: quartz. 

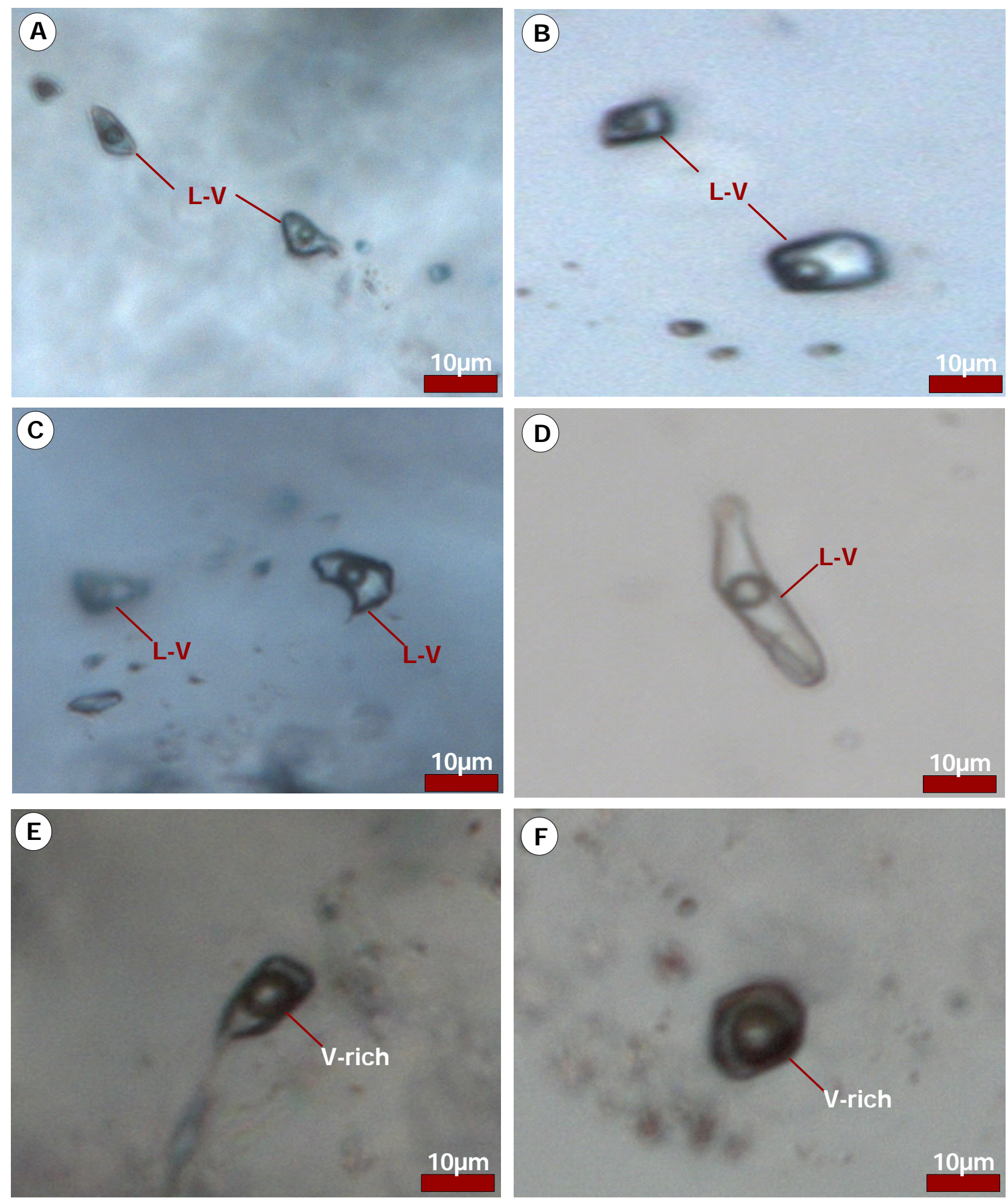

FIGURE 6. Microphotographs showing (a-d) two-phase liquid-rich and (e-f) vapor-rich fluid inclusions in quartz vein samples from the Shwebontha Prospect. (L-liquid; V-vapor). 


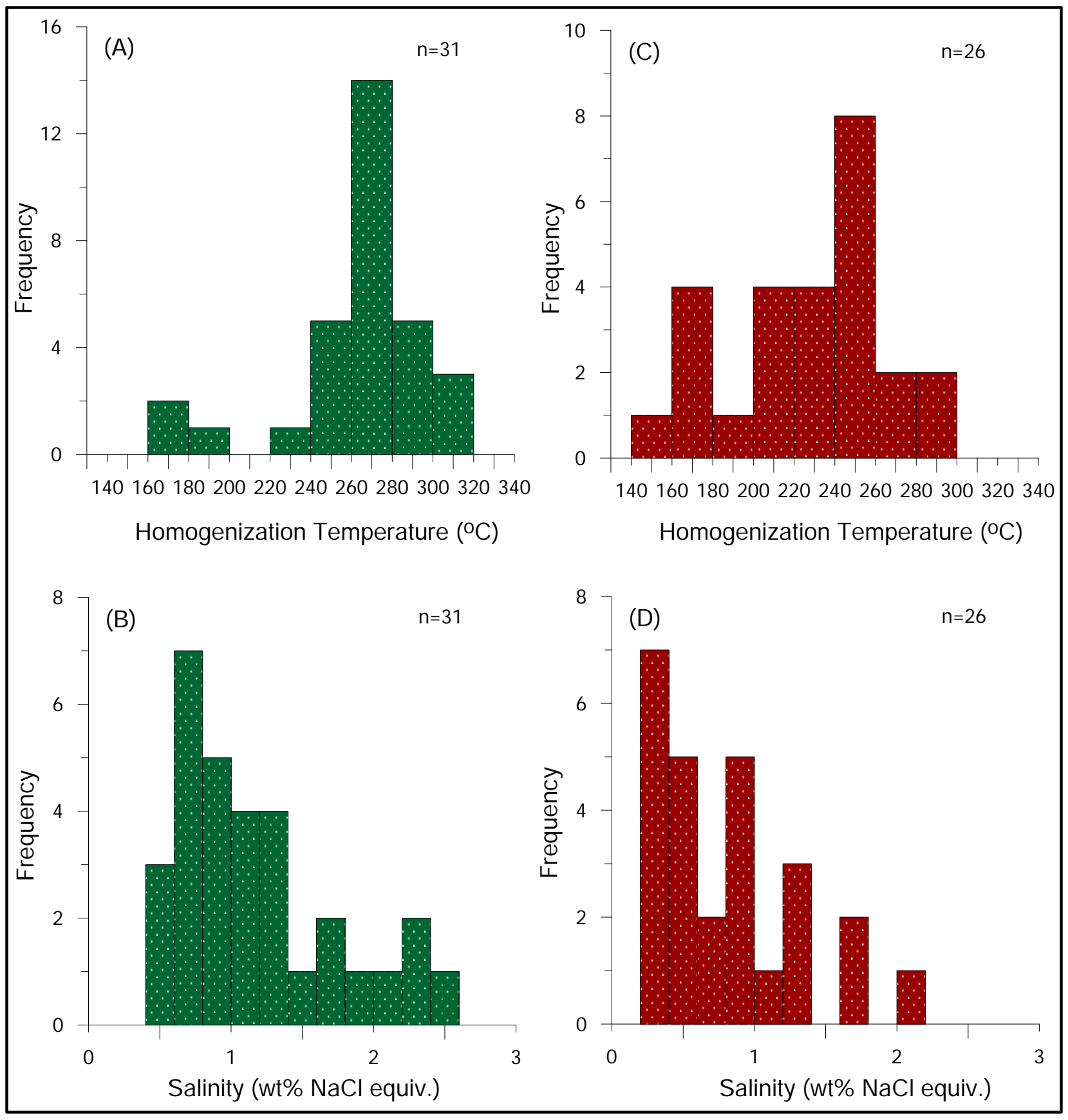

FIGURE 7. Frequency distribution of homogenization temperature (Th) and salinities for fluid inclusions in two different quartz veins ( $a, b$ gold-bearing brecciated quartz vein, and $c$, d-chalcedonic quartz vein) from the Shwebontha Prospect ( $\mathrm{n}=$ number of measurements). 
fluid inclusions are displayed the lower homogenization temperature and strong salinities. In this place, the densities around $0.8 \mathrm{~g} / \mathrm{cm}^{3}$ are most common. It is suggested that consistent with a density derived flow mechanism being responsible for ore mineralization location.

Besides, plotting fluid inclusions of microthermometric data on a bivariate diagram of salinity and homogenization temperature $(T h)$ can deduce the fluid physio-chemical process during the evolution of the extinct hydrothermal system (Figure 9). Salinities were plotted against homogenization temperature $(T h)$ for the Shwebontha fluid inclusions, and a wide range variation of fluid inclusion salinities concerning Th is apparent on the diagram (Figure 10). The significant salinity variations are most likely formed by the isothermal fluids mixing, and a decrease in salinities with slight falling Th is possibly related to surface fluid dilution processes (Figure 10). Based on the fluid inclusion petrography and microthermometric data, the Shwebontha Prospect was not observed for boiling fluid evidence.

The formation temperature of mineralized quartz veins can be estimated from the microthermometric data, especially from $T h$. Under the boiling condition, this temperature generally refers to $T h$ 's histogram distribution (Bodnar et al., 1985). On the contrary, in nonboiling conditions, it can be used to estimate from the first peak histogram. There is no indication of boiling fluid observed from both fluid inclusion and microthermometric data for the Shwebontha mineralized quartz veins. Hence, formation temperature is interpreted from the first peak histogram of Th distribution. It is estimated at $240-260{ }^{\circ} \mathrm{C}$ for chalcedonic quartz veins and $260-280{ }^{\circ} \mathrm{C}$ for gold-bearing brecciated quartz veins, respectively (Figure 7). The formation temperature estimated from the $T h$ data can determine the depth of formation of mineralized veins. The boiling point curve of Haas, 1971 was applied (Figure 11), and the minimum formation depth is estimated at $440 \mathrm{~m}$ for chalcedonic quartz vein and $640 \mathrm{~m}$ for gold-bearing brecciated quartz vein below the paleo-water table, respectively. This depth is corresponding to hydrostatic pressure around 33.1 to 46.4 bars. Indeed, the resulted paleodepth and pressures from the Shwebontha
Prospect area are probably developed in low sulfidation epithermal system of (Sillitoe and Hendenquist, 2003) that generated in the formation of paleo-depth is between 100 and 1000 $\mathrm{m}$ and the hydrostatic pressure of less than 100 bars.

\section{CONCLUSION}

In the Shwebontha Prospect area, gold and base metal mineralization is mainly hosted by volcanic and volcaniclastic rocks. It occurred as open space filling veins and occasionally disseminated nature are also found. There are two main types of mineralization veins, including gold-bearing brecciated quartz vein and chalcedonic quartz vein. Those quartz veins consist of pyrite, galena, sphalerite, chalcopyrite, and gold. Hydrothermal altered the mineralized host rocks and characterized by silicification as well as argillic and propylitic assemblages. Based on the fluid inclusion study, quartz veins' microthermometric measurement is typically characterized by low homogenization temperature (Th) and low salinities values. Most primary fluid inclusions were trapped in quartz crystal along the growth zones and isolated inclusions where liquid-rich two-phase fluid inclusions are dominant. In microthermometric measurement, the values of $T h$ range from 158 to $310{ }^{\circ} \mathrm{C}$, and salinities range from 0.35 to 2.41 wt. $\% \mathrm{NaCl}$ equivalent. A wide range of variation in fluid inclusions salinities and homogenization temperature indicates that fluid dilution and mixing were critical processes during metallic mineralization and the hydrothermal fluid system's evolution.

On the other hand, a compilation of homogenization temperature versus salinities values was used to distinguish the mineral deposit type (Wilkinson, 2001). Shwebontha fluid inclusion data, characterized by low $T h$ and low salinities, were located in the field for epithermal mineralization. Besides, fluid inclusion analysis suggests that the formation temperature of gold-bearing brecciated quartz vein and chalcedonic quartz vein are estimated at 250 $270{ }^{\circ} \mathrm{C}$. Also, their estimated paleo-depth of formation is between $440 \mathrm{~m}$ and $640 \mathrm{~m}$, respectively. Data combination of available data from fluid inclusion types, microthermometric measurement, formation temperature of mineral- 


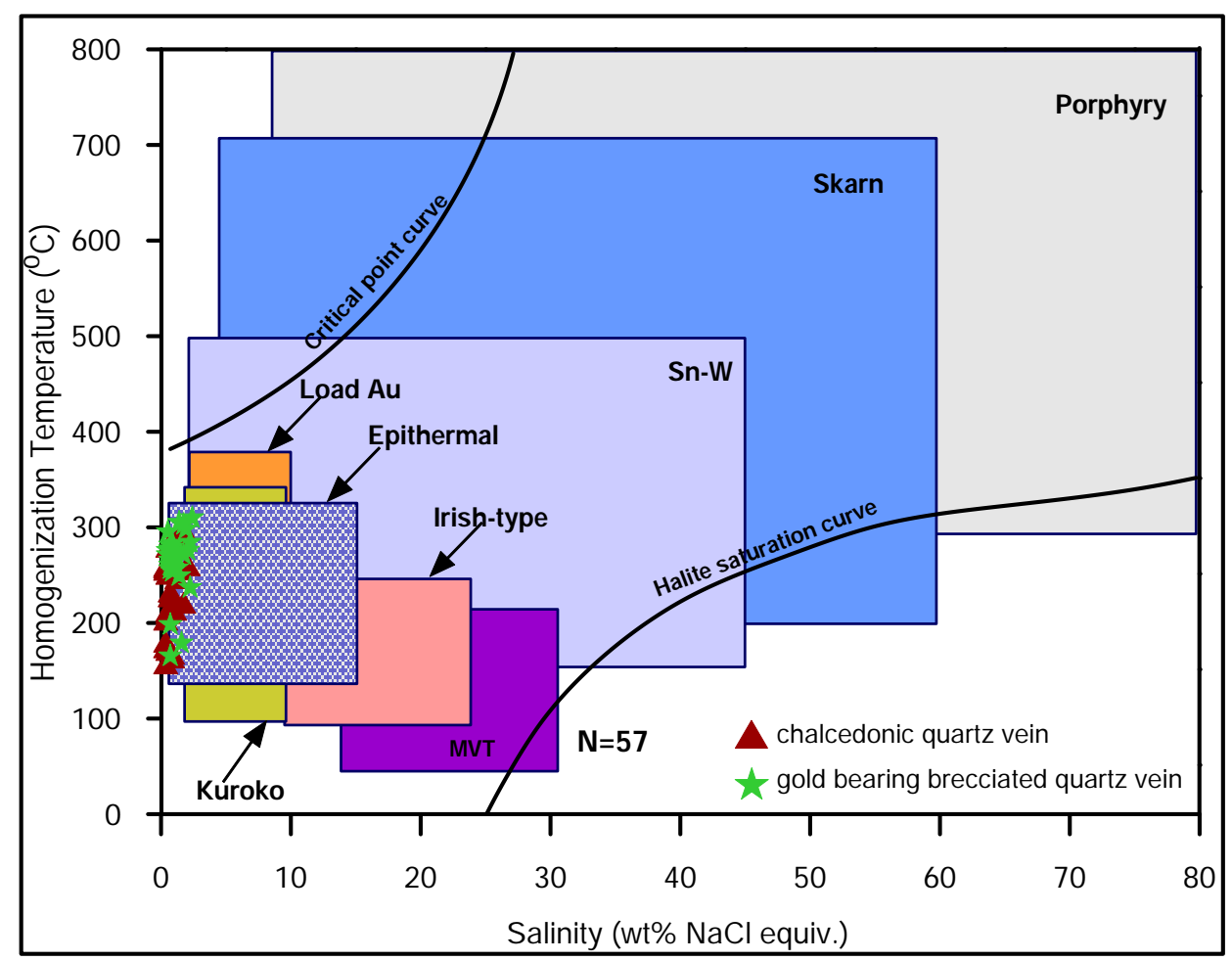

FIGURE 8. Homogenization temperature $\left(T h{ }^{\circ} \mathrm{C}\right)$ versus salinity diagram illustrating typical range for inclusions from different mineral deposit types from Wilkinson (2001) and microthermometric data of fluid inclusions from the deposit plotted on the epithermal field.

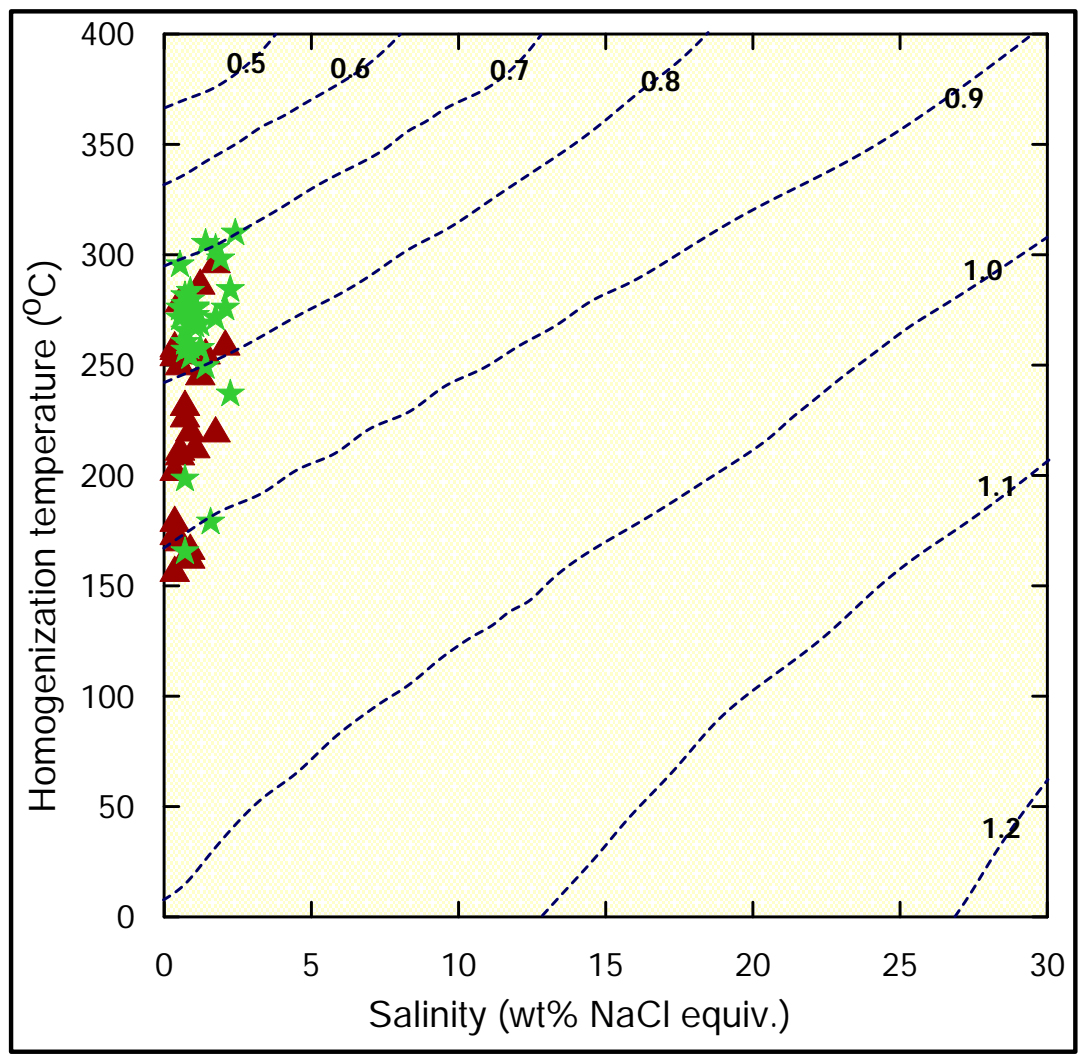

FIGURE 9. Homogenization temperature versus salinity plot diagram from Wilkinson (2001) of the Shwebontha Prospect fluid inclusion and densities $\left(\mathrm{g} / \mathrm{cm}^{3}\right)$ of vapor-saturated $\mathrm{H}_{2} \mathrm{O}-\mathrm{NaCl}$ solution. 


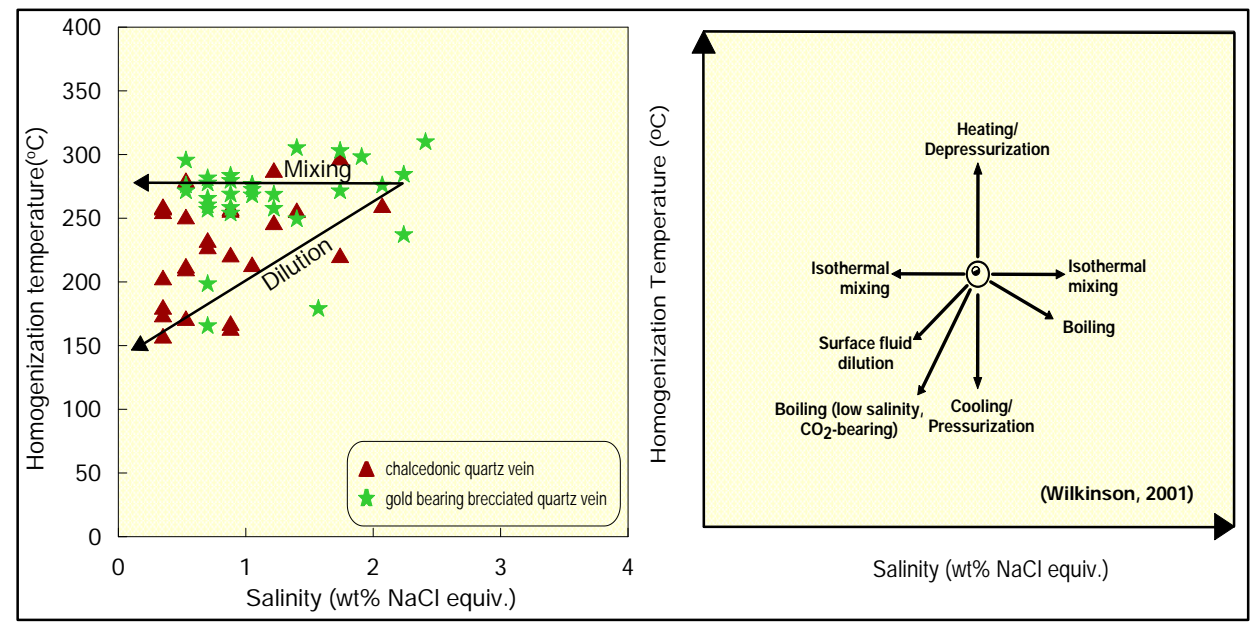

FIGURE 10. Correlation binary plot diagram of salinity (wt.\% $\mathrm{NaCl}$ eq.) versus homogenization temperatures $\left(\mathrm{Th}{ }^{\circ} \mathrm{C}\right)$ from Wilkinson (2001) of the Shwebontha Prospect fluid inclusions.

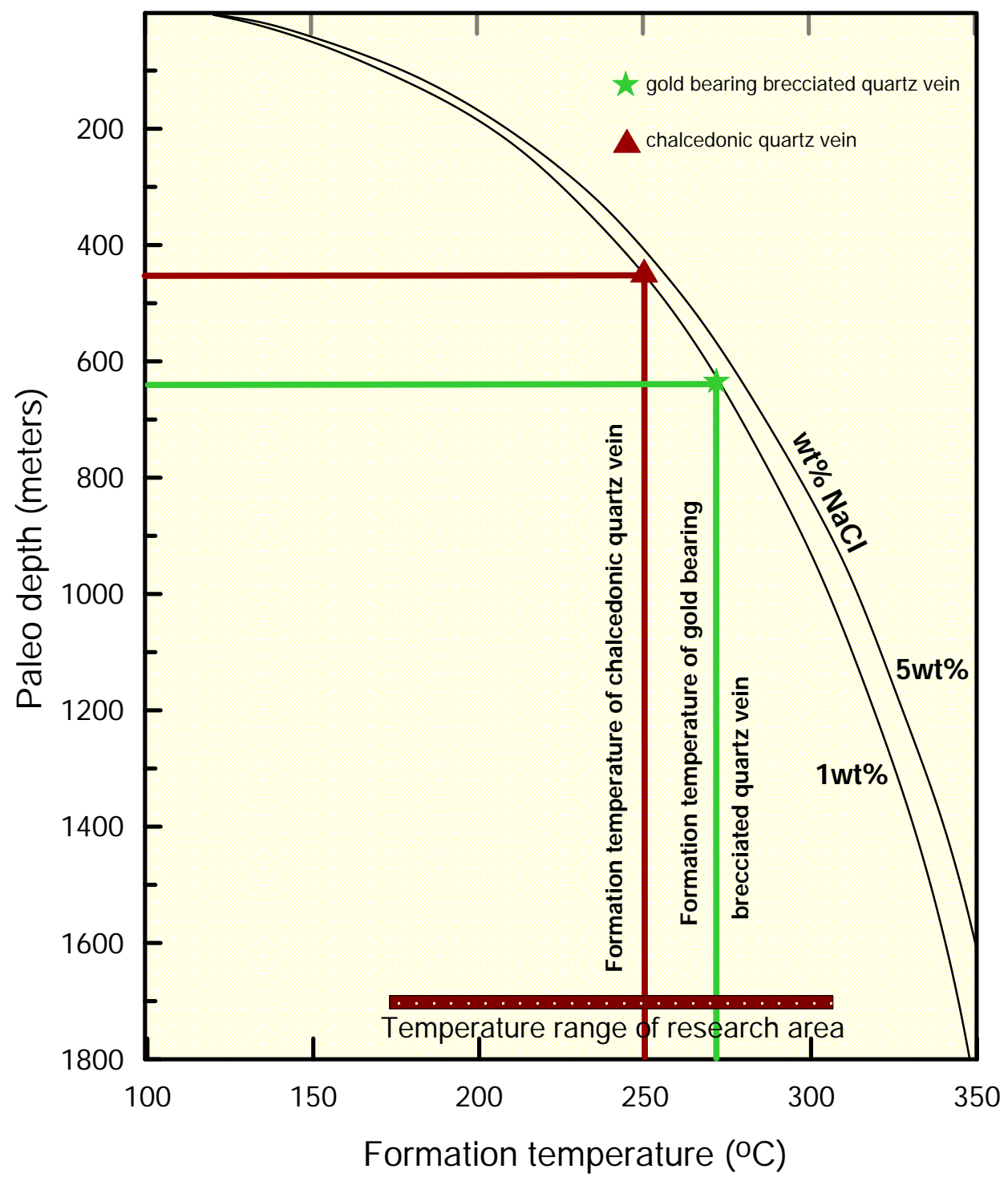

FIGURE 11. Estimation of formation depth of mineralized veins quartz (green line refers to gold-bearing brecciated quartz vein) and (red line refers to chalcedonic quartz vein) from the Shwebontha Prospect by using the boiling point curve of (Haas, 1971). 
ized veins quartz, associated characteristics of hydrothermal alteration types and paleo-depth, it can be concluded that hydrothermal system of the Shwebontha Prospect was developed under the epithermal condition and are also likely to be related to the low temperature and low salinity epithermal setting.

\section{ACKNOWLEDGEMENTS}

We wish to express our sincere gratitude to the AUN/SEED-Net (JICA program) for financial support to carry out this research. We would also like to thank our local people from Monywa Mining District for their permission, support during the field observation, discussion, and supplementary information regarding this research. We are highly appreciative and thankful to Prof. Dr. Akira Imai and Dr. Kotaro Yonezu. Laboratory members from the Department of Earth Resource Engineering, Kyushu University, Japan, for their kind support for laboratory analysis valuable suggestions on data interpretation. We are greatly indebted to two anonymous reviewers for their constructive, valuable comments and valuable suggestions to improve the manuscript.

\section{REFERENCES}

Bodnar, R. J., Burnham, C. W., and Sterner, S.M. (1985) Synthetic fluid inclusions in natural quartz. III. Determination of phase equilibrium properties in the system $\mathrm{H} 2 \mathrm{O}-\mathrm{NaCl}$ to $1000^{\circ} \mathrm{C}$ and 1500 bars, Geochim. Cosmochim. Acta. 49, pp.18611873.

Gardiner, N.J., Searle, M.P., and Robb, L.J. (2015) Neo-Tethyan magmatism and metallogeny in Myanmar - An Andean analogue? Journal of Asian Earth Sciences, 106, p. 197-215.

Haas, J. L. J. (1971) The effect of salinity on the maximum thermal gradient of a hydrothermal system at hydrostatic pressure, Economic Geology 66: 940-946.

Htet, W.T. (2008) Volcanic-hosted gold-silver mineralization in the Monywa mining district, Central Myanmar, Ph.D. dissertation, Mandalay University.

Kirwin, D. (1994) Technical assessment of the Monywa porphyry copper district, Mandalay province, Union of Myanmar. Vol. 1, 2, 3.

Knight, J., Zaw. K. (2015) The geochemical and geochronological framework of the Monywa high sulfidation $\mathrm{Cu}$ and low sulfidation Au-epithermal deposits, Myanmar. Poster No. 104 presented at the SEG 2015 Conference, September, Hobart, Tasmania, Australia, p. 27-30.

Leach. T., Hawk. M., Corlett. G., Simpson. M and Merchant. R. (1996) Petrographic studies of samples from the Kaukmyet, Nache Taung and Shwebontha prospects, Central Myanmar, TLC Report.

Lee, H.Y., Chung, S.L., and Yang, H.M. (2016) Late Cenozoic Volcanism in Central Myanmar: Geochemical Characteristics and Geodynamic Significance, Lithos 245: 174-2190.

Mitchell, A. H. G., Htay, M. T., Htun, K. M., Win, M.N., Oo, T., and Hlaing, T. (2007) Rock Relationships in the Mogok Metamorphic Belt, Tatkon to Mandalay, Central Myanmar. Journal of Asian Earth Sciences, 29, p. 891-910.

Mitchell, A. H. G., Myint, W., Lynn, K., Htay, M.T., Oo. M., and Zaw, T. (2011) Geology of the High Sulfidation Copper Deposits, Monywa Mine, Myanmar, Resource Geology 61: 1-29.

Mitchell, A., Chung, S.L., Oo, T., Lin, T.H., and Hung, C.H. (2012) Zircon U -Pb ages in Myanmar: magmatic-metamorphic events and the closure of a neo-Tethys ocean? Journal of Asian Earth Sciences, 56, p. 1-23.

Oo, T.N., Harijoko, A., and Setijadji, L. D. (2019) Hydrothermal alteration and epithermal gold mineralization system in the Shwebontha Prospect, Monywa mining district, Central Myanmar, The tenth international conference on science and engineering, p. 252-256.

Roedder, E. (1984) Fluid inclusions. Mineralogical Society of America. Reviews in Mineralogy. 2: 644.

Searle, M.P., Noble, S.R., Cottle, J.M., Waters, D.J., Mitchell, A.H.G., Hlaing, T., and Horstwood, M.S.A. (2007) Tectonic Evolution of the Mogok Metamorphic Belt, Burma (Myanmar) Constrained by $\mathrm{U}-\mathrm{Th}-\mathrm{Pb}$ Dating of Metamorphic and Magmatic Rocks, Tectonics, 26p.

Shepherd, T.J., Ranbin, A.H., and Alderton, D.H.M. (1985) In A Practical Guide to Fluid Inclusion Studies, Blackie, Glasgow, 223p.

Sillitoe, R.H., Hedenquist, J.W. (2003) Linkages between volcanotectonic settings, ore fluid compositions, and epithermal precious metal deposits: Society of Economic Geologists Special Publication 10, pp. 315-343.

United Nations, (1979a) Geology and Exploration Geochemistry of the Salingyi-Shinmataung area, central Burma, Technical Report No. 5. Geological Survey and Exploration Project, United Nations Development Programme, DP/UN/BUR72- 002/14, United Nations, New York, 29p.

Wilkinson, J. J. (2001) Fluid inclusions in Hydrothermal Ore Deposits, Lithos 55: 229-272.

Win, K., Kirwin, D. (1998) Exploration, geology and mineralization of the Monywa copper deposits, 
Oo et al.

Central Myanmar, In Porphyry and Hydrothermal Copper and Gold Deposits: A Global Perspective. Proceedings of the Australian Mineral Foundation Conference, Perth, p. 61-74.

Zaw, K. (1990) Geological, petrological and geochemical characteristics of granitoid rocks in Myanmar: with special reference to the asso- ciated W-Sn mineralization and their tectonic setting. Journal of Asian Earth Sciences, 4, p. 293-2335.

Zaw, K., Swe. M., Myint, T.A., and Knight. J. (2017) Copper deposits of Myanmar. Geology, Resources, and Tectonics, the Geological Society (London) Memoir, 48: 573-588.. 